\title{
COMUNICACIÓN
}

\section{Two cestode species in Brazilian turkeys, Meleagris gallopavo (Galliformes, Phasianidae): pathology induced by Hymenolepis cantaniana and occurrence of Raillietina tetragona}

\author{
ROBERTO MAGALHÃES PINTO*, BEATRIZ BRENER*, \\ RODRIGO CALDAS MENEZES** y ROGÉRIO TORTELLY*
}

\begin{abstract}
The pathology induced in turkeys (Meleagris gallopavo) by one cestode species Hymenolepis cantaniana is described together with data on prevalence, mean infection and range of worm burdens. $\boldsymbol{H}$. cantaniana occurred with a prevalence of $5.0 \%$ in the 40 examined hosts in a range of 14-21 specimens and a mean intensity of 17.5. Gross lesions were not observed in the parasitized birds. Lesions due to $\boldsymbol{H}$. cantaniana mainly consisted of multiple segments of parasites, together with a mild mixed inflammatory reaction with the presence of mononuclear cells and heterophils or severe transmural inflammatory processes, characterized by the presence of mononuclear cells along the muscular and serosa layers of the intestinal villi and crypts. These are the first pathological findings related to the presence of cestodes in turkeys to be reported in Brazil so far. Raillietina tetragona, not pathogenic to the present investigated turkeys, occurred with a low prevalence and range of infection of $2.5 \%$ and $1-2$ worms, respectively.
\end{abstract}

Key words: cestodes, Hymenolepis cantaniana, pathology, Raillietina tetragona, occurrence, birds, Meleagris gallopavo, turkeys, Brazil.

\section{INTRODUCTION}

Recently, results described the pathogenic action of trematodes, nematodes, and one protozoan species infecting turkeys from backyard flocks in Brazil ${ }^{1-3}$. The present data are related to the pathology induced by Hymenolepis cantaniana (Polonio, 1860) Ransom, 1909 and the occurrence of Raillietina tetragona Molin, 1858 (Eucestoda, Davaineidae) infecting specimens of Brazilian turkeys, Meleagridis gallopavo.

\section{MATERIALS AND METHODS}

From May 2004 to October 2005, forty adult specimens, 19 males, 21 females of turkeys $(M$. gallopavo Linnaeus, 1758), weight 950-8,870g, obtained from backyard flocks of different localities in the State of Minas Gerais, Brazil (19

\footnotetext{
* Laboratório de Helmintos Parasitos de Vertebrados, Instituto Oswaldo Cruz-Fiocruz, Av. Brasil 4365, 21045-900 Rio de Janeiro, RJ, Brasil.

** Instituto de Pesquisas Evandro Chagas-Fiocruz, Rio de Janeiro, RJ, Brasil.

*** Departamento de Patologia, Faculdade de Veterinária, Universidade Federal Fluminense, Niterói, RJ, Brasil.
} 
animals), namely Candeias $\left(20^{\circ} 46^{\prime} 01^{\prime} \mathrm{S}\right.$,

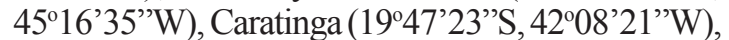
Juiz de Fora $\left(21^{\circ} 45^{\prime} 51^{\prime \prime} \mathrm{S}, 43^{\circ} 21^{\prime} 01^{\prime}\right.$ 'W),

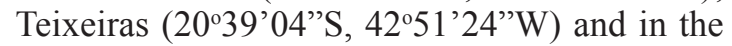
State of Rio de Janeiro, Brazil (21 animals), namely Cantagalo (21 ${ }^{\circ} 58^{\prime} 52^{\prime}$ 'S, 42 $\left.22^{\prime} 05^{\prime \prime} \mathrm{W}\right)$, Maricá (22 $55^{\prime} 10^{\prime \prime} \mathrm{S}, 42^{\circ} 49^{\prime} 07^{\prime}$ 'W), Niterói (22 $\left.2^{\circ} 3^{\prime} 00^{\prime \prime} \mathrm{S}, 4^{\circ} 06^{\prime} 13^{\prime \prime} \mathrm{W}\right)$ [Várzea das Moças district], Piraí (22³7'45”S, 4353'53”W), Rio

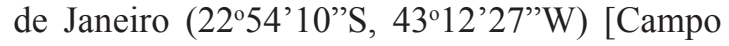
Grande district], Teresópolis (22024'44”S, $\left.42^{\circ} 57^{\prime} 56^{\prime \prime} \mathrm{W}\right)$ were investigated for helminths. After individual clinical evaluation, birds were killed and submitted to necropsy in accordance to the usual technique ${ }^{4}$. Organs were opened in Petri dishes containing $0.85 \% \mathrm{NaCl}$ solution. Cestodes were transferred to tap water and maintained overnight under $-8^{\circ} \mathrm{C}$ to be later, fixed in cold AFA (ethanol 70 $0^{\circ} \mathrm{GL}, 93 \mathrm{ml}$; formaldehyde, $5 \mathrm{ml}$; acetic acid, $2 \mathrm{ml}$ ). Portions of the parasitized organs were removed and immediately fixed in $10 \%$ formalin, to be further routinely processed for paraffin embedding. Five micrometers thick sections were stained with hematoxylin and eosin (H.E.). The recovered cestodes were counted under a stereomicroscope and after, stained with alcoholic chloride carmine, dehydrated in an ethanol series $\left(70^{\circ}-100^{\circ} \mathrm{GL}\right)$, cleared in phenol and mounted in balsam. Classification of the cestodes is according as indicated elsewhere ${ }^{5}$. Micrograph was obtained in a Zeiss Axyophot brightfield microscope. The development of this study has been authorized by the Committee of Ethics for the Use of Animals (CEUA/Fiocruz) no. P0095-01.

\section{RESULTS}

Eight turkeys (20\%) out of the 40 investigated specimens were positive for cestodes. Gross lesions were absent in animals infected either with $H$. cantaniana or $R$. tetragona. Specimens of the former species were recovered from two turkeys from Maricá, RJ, with a prevalence of $5 \%$, intensity of infection of $14-21$ parasites and mean intensity of 17.5. From the other six animals, two also from Maricá, and three from Teixeiras, RJ, and one from Juiz de Fora, MG, only fragments (probably of $H$. cantaniana) were observed. Microscopic lesions due to this species, revealed multiple segments of the parasites and a discrete mixed inflammatory reaction of mononuclear cells and heterophils of the intestinal villi and crypts Nevertheless, in another animal harboring $21 \mathrm{H}$. cantaniana specimens, segments of the intestine with an accentuated transmural inflammatory process, characterized by a mixed inflammatory infiltrate, with the predominance of mononuclear cells distributed along the muscular and serosa were observed. On what concerns Raillietina tetragona that appeared with a low prevalence and range of infection of $2.5 \%$ and 1-2, respectively, microscopic lesions were absent in the single infected bird.

\section{DISCUSSION}

Frequently, cestodes have been reported from turkeys worldwide, with lower worm burden rates when compared to those of the parasitizing nematodes. In despite of those previous results, few are related to the species presented here, may be due to the different geographical regions in which data have been reported so far. In Brazil, there is only a reference of specimens of Hymenolepis sp. infecting turkeys ${ }^{6}$ and overseas ${ }^{7}$, results related to the finding of $H$. cantaniana specimens in the small intestine in $4.1 \%$ of the 390 turkeys investigated for helminths in the USA, without pathological approaches, were obtained. Considering the occurrence of $5 \%$ in the animals presented here and assuming that the specimens of Hymenolepis sp. recovered from Brazilian turkeys belong to $H$. cantaniana, our infection rates $(15 \%)$ with this cestode species are significantly higher, when compared to the $4.1 \%$ previously reported.

Taking into account the fact that, in the present study, one of the specimens of M. gallopavo presented a severe mixed transmural inflammatory process, with the presence of mononuclear cells distributed along the serosa and muscular layers, this can be taken as an indicator of physiological changes in the host, that eventually may interfere in the productivity of the parasitized turkeys and thus, promoting losses to raisers.

Interestingly, in despite of the presence of the double crown of hooks and suckers armed with spines, lesions due to $R$. tetragona were not observed in the single turkey infected with this species. This fact may be due to the very low parasite burden observed, that not permitted a further intestinal attrition, since only two worms 
were found free in the lumen of the parasitized bird, at the moment of recovery, somehow justifying the absence of microscopic lesions. Conversely, specimens of $H$. cantaniana, although unarmed with bothridial hooks and presenting spineless suckers, were deeply burrowed in the intestinal mucosa, and thus, able to induce microscopic changes in the presently studied birds.

Raillietina tetragona has already been referred in Brazilian turkeys ${ }^{8,9}$ and, although the species is frequently reported from Galliformes hosts worldwide, data on its occurrence in Brazil are very poor; perhaps, the very low prevalence and intensity of infection of turkeys with $R$. tetragona can serve as indicators for the lack of previous reports of this cestode species in Brazilian birds to date.

The life-cycle of the species was described as heteroxenous and ants are the intermediate hosts. Specimens of R. tetragona are considered of economic importance, since they can destroy the intestinal walls, with the deep penetration of the scolex in the muscular mucosa, causing serious disturbances to the infected hosts ${ }^{10}$. Taking into account that in the present study only one of the turkeys $(2.5 \%)$ was parasitized with two specimens of $R$. tetragona, this situation could not be confirmed.

The presence of Raillietina sp. was also reported in wild turkeys from the USA ${ }^{11}$ as well as of $R$. tetragona, with indication of prevalences from 0.5 to $15 \%$ of parasitism ${ }^{12}$.

\section{RESUMO}

Duas espécies de cestóides em perus, Meleagris gallopavo (Galliformes, Phasianidae), no Brazil: patologia induzida por Hymenolepis cantaniana e ocorrência de Raillietina tetragona.

A patologia induzida em perus pelo cestóide H. cantaniana é descrita, com dados sobre prevalência, intensidade média e amplitude das cargas parasitárias. $\boldsymbol{H}$. cantaniana ocorreu com uma prevalência de $5.0 \%$ nas 40 aves examinadas, com intensidade média de 17.5 e amplitude de 14-21 espécimes de cestóides. Não foram observadas lesões macroscópicas nos perus parasitados. As lesões provocadas por $\boldsymbol{H}$. cantaniana eram representadas, principalmente, ou por múltiplos segmentos dos parasitos, acompanhados por discreta reação inflamatória mista com a presença de células mononucleares e heterófilos, ou por severos processos inflamatórios transmurais, caracterizados pela presença de células mononucleares, ao longo das camadas muscular e serosa das vilosidades e criptas intestinais. Estes representam os primeiros achados patológicos relacionados à presença de cestóides em perus a serem relatados no Brasil.

Raillietina tetragona, não patogênica para as aves investigadas, ocorreu com baixa prevalência e amplitude de infecção de $2.5 \%$ e $1-2$ parasitos, respectivamente.

\section{REFERENCIAS}

1.- BRENER B, TORTELLY R, MENEZES R C, et al. Prevalence and pathology of the nematode Heterakis gallinarum, the trematode Paratanaisia bragai, and the protozoan Histomonas meleagridis in the turkey, Meleagris gallopavo. Mem Inst Oswaldo Cruz 2006; 101: 677-81.

2.- BRENER B, TORTELLY R, MUNIZ-PEREIRA L C, PINTO R M. First report of Cheilospirura hamulosa (Diesing, 1851) (Nematoda, Acuarioidea) in turkeys, Meleagris gallopavo (L., 1758) (Aves, Phasianidae) in Brazil: prevalence and pathology. Arq Bras Med Vet Zootec 2006; 58: 287-90.

3.- PINTO R M, BRENER B, TORTELLY R, et al. Capillariid nematodes in Brazilian turkeys, Meleagris gallopavo (Galliformes, Phasianidae): pathology induced by Baruscapillaria obsignata and Eucoleus annulatus (Trichinelloidea, Capillariidae). Mem Inst Oswaldo Cruz 2008; 103: 295-7.

4.- ZANDER D V, BERMUDEZ A J, MALLINSON E T. Chapter 1: 3-45. Principles of disease prevention: diagnosis and control. In: BW Calnek, HJ Barnes, CW Beard, LR MCDouglad, YM Saif. Diseases of Poultry, 10th ed., Iowa State University Press, Ames, 1080 p. 1997.

5.- KHALIL LF, JONES A, BRAY RA. Keys to the Cestode Parasites of Vertebrates, Cambridge University Press, Cambridge, 751 p. 1994.

6.- COSTA HMA, LEITE A C R, GUIMARÃES M P, LIMA W S. Distribuição de helmintos parasitos de animais domésticos no Brasil. Arq Bras Med Vet Zootec 1986; 38: 465-79.

7.- MAXFIELD B G, REID W M, HAYES $F$ A. Gastrointestinal helminths from turkeys in southeastern United States. J Wild Manag 1963; 27: 261-71.

8.- CARVALHO J C M. Contribuição para o conhecimento da fauna helmintológica de Minas Gerais. Ceres 1940; 1: 411-23.

9.- FREITAS M G. Lista de helmintos parasitos dos animais domésticos de Minas Gerais. Arq Esc Sup Vet 1951; 10: 373-81. 
10.- HORSFALL M W. Observations on the life history of Raillietina echinobotrida and $R$. tetragona (Cestoda). J Parasitol 1938; 24: 409-21.

11.- HOPKINS B A, SKEELES J K, HOUGHTEN G E, et al. A survey of infectious diseases in wild turkeys (Meleagris gallopavo silvestris) from Arkansas. J Wildl Dis 1990; 26: 468-72.

12.- MC JUNKIN J W, APPLEGATE R D, ZELMER D A. Enteric helminths of juvenile and adult wild turkeys
(Meleagris gallopavo) in Eastern Kansas. Avian Dis 2003; 47: 1481-5.

Acknowledgements: To the Conselho Nacional de Desenvolvimento Científico e Tecnológico (CNPq), Brazil, for partial financial support in this investigation to $\mathrm{Dr}$ Roberto Magalhães Pinto; to Rodrigo Méxas, Laboratório de Produção e Tratamento de Imagens, Instituto Oswaldo Cruz, for technical assistance with the figure.

Correspondence to:

Dr Roberto Magalhães Pinto

Avenida Brasil, 4365, CEP 21045-900, Rio de Janeiro, RJ, Brasil.

E-mail: rmpinto@ioc.fiocruz.br. 